
5

\title{
Post-vaccination SARS-COV-2 among healthcare workers in New Jersey: a genomic epidemiological study
}

Barun Mathema ${ }^{1, a}$, Liang Chen, ${ }^{2,3, a}$, Kar Fai Chow ${ }^{4}$, Yanan Zhao ${ }^{2,3}$, Michael C Zody ${ }^{5}$, Jose R Mediavilla ${ }^{2}$, Marcus H Cunningham ${ }^{2}$, Kaelea Composto ${ }^{2}$, Annie Lee $^{2}$, Dayna M Oschwald ${ }^{5}$, Soren Germer ${ }^{5}$, Samantha Fennessey ${ }^{5}$, Kishan Patel ${ }^{4}$, David Wilson ${ }^{6}$, Ann Cassell ${ }^{6}$, Lauren Pascual $^{7}$, Andrew $\mathrm{Ip}^{7}$, André Corvelo ${ }^{5}$, Sophia Dar ${ }^{4}$, Yael Kramer ${ }^{4}$, Tom Maniatis ${ }^{5}$, David S Perlin $^{2,3}$, Barry N Kreiswirth ${ }^{2^{*}}$

1. Mailman School of Public Health, Columbia University Irving Medical Center, New York, NY, USA

2. Hackensack Meridian Health Center for Discovery and Innovation, Nutley, NJ, USA

3. Hackensack Meridian School of Medicine, Nutley, NJ 07110, USA

4. Hackensack Meridian Health Biorepository, Hackensack, NJ. USA

5. New York Genome Center, New York, NY, USA

6. Hackensack Meridian Health BI Analytics, Edison, NJ, USA

7. John Theurer Cancer Center, Outcomes Division, Hackensack University Medical Center, Hackensack, NJ, USA.

${ }^{a}$ Barun Mathema and Liang Chen contributed equally to this article. The order of co-first authors was determined by discussion and mutual agreement between the two co-first authors.

*Correspondence to: Dr. Barry N Kreiswirth, Barry.Kreiswirth@hmh-cdi.org

Running title: Post-vaccination COVID-19 in New Jersey 
medRxiv preprint doi: https://doi.org/10.1101/2021.06.30.21259761; this version posted July 5, 2021. The copyright holder for this preprint (which was not certified by peer review) is the author/funder, who has granted medRxiv a license to display the preprint in perpetuity. It is made available under a CC-BY-NC-ND 4.0 International license .

\section{ABSTRACT}

28 Emergence of SARS-CoV-2 with high transmission and immune evasion potential, the so-called

29 Variants of Concern (VOC), is a major concern. We describe the early genomic epidemiology of

30 SARS-CoV-2 recovered from vaccinated healthcare professionals (HCP). Our post-vaccination

31 COVID-19 symptoms-based surveillance program among HCPs in a 17-hospital network,

32 identified all vaccinated HCP who tested positive for COVID-19 after routine screening or after

33 self-reporting. From 01/01/2021 to 04/30/2021, 23,687 HCP received either mRNA-1273 or

34 BNT162b2 mRNA vaccine. All available post-vaccination SARS-CoV-2 samples and a random

35 collection from non-vaccinated patients during the similar timeframe were subjected to VOC

36 screening and whole genome sequencing (WGS). $62 \%(23,697 / 37,500)$ of HCPs received at

37 least one vaccine dose, with $95 \%(22,458)$ fully vaccinated. We detected $138(0.58 \%$,

38 138/23,697) COVID-19 cases, 105 among partially vaccinated and $33(0.15 \%, 33 / 22,458)$

39 among fully vaccinated. Five partially vaccinated required hospitalization, four with supplemental

40 oxygen. VOC screening from 16 fully vaccinated HCPs identified 6 (38\%) harboring N501Y and

$411(6 \%)$ with E484K polymorphisms; concurrent non-vaccinated samples was 37\% $(523 / 1404)$

42 and $20 \%(284 / 1394)$, respectively. There was an upward trend from January to April for

$43 \mathrm{E} 484 \mathrm{~K} / \mathrm{Q}(3 \%$ to $26 \%)$ and N501Y (1\% to $49 \%)$. WGS analysis from vaccinated and non-

44 vaccinated individuals indicated highly congruent phylogenies. We did not detect an increased

45 frequency of any RBD/NTD polymorphism between groups $(\mathrm{P}>0.05)$. Our results support robust

46 protection by vaccination, particularly among recipients of both doses. Despite VOCs

47 accounting for over $40 \%$ of SARS-CoV-2 from fully vaccinated individuals, the genomic diversity

48 appears to proportionally represent those among non-vaccinated populations.

49

50

51 
medRxiv preprint doi: https://doi.org/10.1101/2021.06.30.21259761; this version posted July 5, 2021. The copyright holder for this preprint (which was not certified by peer review) is the author/funder, who has granted medRxiv a license to display the preprint in perpetuity. It is made available under a CC-BY-NC-ND 4.0 International license.

\section{IMPORTANCE}

53 A number of highly effective vaccines have been developed and deployed to combat the

54 COVID-19 pandemic. The emergence and epidemiological dominance of SARS-CoV-2 mutants, 55 with high transmission potential and immune evasion properties, the so-called Variants of 56 Concern (VOC), continues to be a major concern. Whether these VOCs alter the efficacy of the 57 administered vaccines is of great concern, and a critical question to study. We describe the 58 initial genomic epidemiology of SARS-CoV-2 recovered from vaccinated healthcare

59 professionals and probe specifically for VOC enrichment. Our findings support the high-level of

60 protection provided by full vaccination despite a steep increase in the prevalence of

61 polymorphisms associated with increased transmission potential (N501Y) and immune evasion

$62(\mathrm{E} 484 \mathrm{~K})$ in the non-vaccinated population. Thus, we do not find evidence of VOC enrichment

63 among vaccinated groups. Overall, the genomic diversity of SARS-CoV-2 recovered post-

64 vaccination appears to proportionally represent the observed viral diversity within the 65 community.

66

67 Key words: COVID-19, SARS-CoV-2, Variants of Concern, vaccine, breakthrough, spike 68 protein

69

70 
medRxiv preprint doi: https://doi.org/10.1101/2021.06.30.21259761; this version posted July 5, 2021. The copyright holder for this preprint (which was not certified by peer review) is the author/funder, who has granted medRxiv a license to display the preprint in perpetuity. It is made available under a CC-BY-NC-ND 4.0 International license .

\section{INTRODUCTION}

72 Since the beginning of the pandemic in 2020, SARS-CoV-2 has infected and spread within an

73 immunologically naïve global population $(1,2)$. With the application of convalescent plasma and

74 therapeutic antibody treatment, along with highly effective vaccines, the virus is now starting to 75 experience the immune pressure that will ultimately shape its evolutionary trajectory (3). Recent 76 evidence indicates that SARS-CoV-2 can mutate and evade immunity and challenge the 77 efficacy of emerging vaccines and intrinsic and extrinsic antibodies (i.e., natural by infection and 78 antibody therapeutics) $(3,4)$.

79 The reports of mutants, known as Variants of Concerns (VOCs) that exhibit increased 80 transmission or immune evasion, or both, have been reported in different global regions and 81 predominant lineages have been genotyped (5). Of note, three VOCs, B.1.1.7 (recently named

82 Alpha) (6), B.1.351 (Beta) (7), and P.1 (Gamma) (8) containing prominent mutations in the spike 83 protein, emerged in the UK, South Africa and Brazil, respectively, and more recently, B.1.617.2 84 (Delta) (9) emerged in India and has spread globally. The mapping of specific mutations in the 85 spike protein has revealed strong evidence of convergent evolution, and particularly the E484K 86 polymorphism, which is able to evade certain monoclonal therapy and it is less responsive to 87 neutralizing antibodies from recovered patients. This mutant shows reduced response to 88 convalescent plasma and reported reinfections and it has been identified in discrete lineages in 89 different geographic locations and associated with variant clones with increased incidence (4).

90 The impact of these antibody escape mutants harboring VOCs on driving community incidence 91 and whether they alter the efficacy of the administered vaccines is of great concern.

92 In this report, we describe the initial genomic epidemiology of SARS-CoV-2 recovered from

93 vaccinated healthcare professionals (HCPs) within a large healthcare network in New Jersey.

94 We specifically probe whether specific SARS-CoV-2 variants skew viral diversity indicative of

95 vaccine-induced selection; and compare against a random collection of SARS-CoV-2 recovered

96 from non-vaccinated individuals during the same time period. Although we find steep increases 
medRxiv preprint doi: https://doi.org/10.1101/2021.06.30.21259761; this version posted July 5, 2021. The copyright holder for this preprint (which was not certified by peer review) is the author/funder, who has granted medRxiv a license to display the preprint in perpetuity. It is made available under a CC-BY-NC-ND 4.0 International license .

97 in variants harboring E484K and N501Y among community samples, our early genomic

98 assessment does not indicate specific variant enrichment among post-vaccinated individuals.

99 We find that viral genomes among vaccinated individuals largely reflect the viral diversity among

100 non-vaccinated populations.

101

102 RESULTS

103 COVID-19 post-vaccination surveillance program: demographic and clinical 104 characteristics of COVID-19 cases.

105 From December 2020 to April 2021, 23,697 of 37,500 HCPs (62\%) received at least one dose

106 of an mRNA vaccine, and $22,458(59 \%, 22,458 / 37,500)$ received both vaccine doses. Among

107 vaccinated employees, 12,878 (54\%) received mRNA-1273 (Moderna) and 10,819 (46\%)

108 received BNT162b2 (Pfizer/BioNTech) mRNA COVID-19 vaccine. Of the 23,697 vaccinated

109 (single and both doses) employees, our surveillance program detected $138(0.58 \%, 138 / 23,697)$

110 COVID-19 cases, 105 of these were among employees who received only one dose and 33

$111(0.15 \%, 33 / 22,458)$ with both doses.

112

113 Among the 138 post-vaccinated COVID-19 cases, 74 were vaccinated with the Pfizer/BioNTech

114 vaccine and 64 were vaccinated with the Moderna preparation. Cases were reported from nine

115 hospitals. Demographic information was not available for 17 employees. Of the remaining 121

116 employees, most cases were white (68\%) and female (74\%) with a median age of 45 (ranging

117 from 19-77). Twenty-one employees (17\%) were documented to have asymptomatic infection.

118 Of those that were symptomatic, five individuals requiring hospitalization received only one dose

119 and had recorded BMI of $>25$ (4 individuals with BMI $>30$ ) and four of these patients required

120 supplemental oxygen. The majority of the vaccine breakthroughs, $76 \%(105 / 138)$, occurred from

121 1-113 days after the initial dose with a median of 10 days, while $23 \%$ (33/138) occurred 4-104

122 days after the second dose with a median of 22 days. 
medRxiv preprint doi: https://doi.org/10.1101/2021.06.30.21259761; this version posted July 5, 2021. The copyright holder for this preprint (which was not certified by peer review) is the author/funder, who has granted medRxiv a license to display the preprint in perpetuity. It is made available under a CC-BY-NC-ND 4.0 International license .

124 Screening of post-vaccinated SARS-CoV-2 infections indicate the rise in E484K and $125 \quad$ N501Y variants.

126 To further characterize the SARS-CoV-2 genotypes recovered from the post-vaccinated 127 individuals, we examined the spread of key mutations underlying VOCs (i.e., B.1.1.7) in New 128 Jersey using a high-throughput molecular beacon assay designed to screen for polymorphisms $129 \mathrm{~N} 501 \mathrm{Y} / \mathrm{T}$ and $\mathrm{E} 484 \mathrm{~K} / \mathrm{Q}$ in the RBD region (10). Among $138 \mathrm{HCPs}, 83$ swabs were available for 130 rapid screening providing 76 genotypic results (60 from partial and 16 from fully vaccinated).

131 There were 3 and 6 viral samples with E484K and N501Y polymorphisms respectively (Figure 132 1). Among 16 fully vaccinated HCPs, we found 1 (6.3\%) and 6 (38\%) samples with E484K and 133 N501Y mutations, respectively.

134 To contextualize the prevalence of E484K and N501Y mutations among the non-vaccinated 135 population, we randomly sampled 1,404 SARS-CoV-2 positive swabs (from a total of 3,000 136 positive COVID-19 swabs) from January 2021 to April 2021 within our hospital network. Overall, 137 we detected 284 E484K/Q (284/1392, 20.4\%, 12 samples failed in the E484 detection in 138 comparison with N501Y) and 523 N501Y (523/1404, 37.3\%) mutants (Figure 2). The prevalence 139 of $\mathrm{E} 484 \mathrm{~K} / \mathrm{Q}$ and $\mathrm{N} 501 \mathrm{Y}$ from January to April, was $3.2 \%$ to $25.7 \%$ and $1.0 \%$ to $49.3 \%$, 140 respectively (Figure 2).

142 SARS-CoV-2 from vaccinated individuals is diverse and does not indicate predominant 143 genotypes or genetic characteristics.

144 To understand the population structure of SARS-CoV-2 post-vaccination, we first analyzed 145 WGS data for 68 available SARS-CoV-2 isolates from 83 symptomatic COVID-19 cases 146 included in this study. WGS failed for 15 samples due to high Ct values, suggestive of low viral 147 burden. We specifically probed whether specific variants or mutations were overrepresented 148 among SARS-CoV-2 recovered from vaccinated individuals. The 68 genomes were divided into 
medRxiv preprint doi: https://doi.org/10.1101/2021.06.30.21259761; this version posted July 5, 2021. The copyright holder for this preprint (which was not certified by peer review) is the author/funder, who has granted medRxiv a license to display the preprint in perpetuity. It is made available under a CC-BY-NC-ND 4.0 International license .

14921 different Pangolin lineages with B.1.2 the most common (24/68, 35\%) (Figure 3). We noted

150 distinct amino acid changes or deletions at 20 sites within the $\mathrm{N}$-terminal domain (NTD) or

151 receptor-binding domain $(\mathrm{RBD})$ regions of the spike protein. Mutations associated with antibody

152 evasion - L452R, T478K, E484K and S494P - were found in 3, 1, 3 and 2 genomes,

153 respectively. We did not detect any genomes with more than two of the four polymorphisms.

154 The N501Y mutation was found in $4 \%(3 / 68)$ of the genomes, and all belonged to the VOC

155 B.1.1.7 lineage. We recorded 3 viral samples harboring the E484K mutation, two belonged to

156 the B.1.526 lineage first identified in New York $(11,12)$ and one from the R.1 lineage.

157 Importantly, among the 9 individuals fully vaccinated (i.e., $\geq 14$ days post-second dose) we note

1581 and 2 samples harboring E484K and N501Y polymorphisms, respectfully. There were no

159 samples from fully vaccinated HCPs with both E484K and N501Y.

160 To compare viral diversity from vaccinated and non-vaccinated individuals, we randomly

161 selected 281 SARS-CoV-2 samples recovered from non-vaccinated patients within the

162 Hackensack Meridian Health $(\mathrm{HMH})$ network during the same time period for genomic

163 characterization by WGS (Figure 3). Among them, 38 different Pangolin lineages were

164 identified, including 18 lineages found in the vaccinated population. B.1.526 $(n=33)$ and its sub-

165 lineages (B.1.526.1, $n=26$, and B.1.526.2, $n=15)$ were the most common $(74 / 281,26.3 \%)$,

166 followed by B.1.2 (35, 12.5\%), B.1.1.7 (28, 10\%) and B.1.575 (26, 9.3\%). In addition, 5 P.1

167 (20J/501Y.V3) and 1 B.1.617.1 (Kappa) were found among the 281 samples. Mutations or

168 deletions were detected in 54 sites within the S protein RBD or NTD region, including 18 sites

169 found in the vaccinated samples. L452R, T478K/I, E484K/Q and S494P mutations were

170 identified in 32, 8, 40 and 29 genomes, respectively. Compared with the non-vaccinated

171 samples, we did not detect a significant increase in the frequency of any RBD/NTD mutations or

172 deletions among the vaccinated group $(P>0.05)$.

173

174 DISCUSSION 
medRxiv preprint doi: https://doi.org/10.1101/2021.06.30.21259761; this version posted July 5, 2021. The copyright holder for this preprint (which was not certified by peer review) is the author/funder, who has granted medRxiv a license to display the preprint in perpetuity. It is made available under a CC-BY-NC-ND 4.0 International license .

175 Rapid expansion and contraction of SARS-CoV-2 populations coupled with increasing anti-CoV-

1762 immunity dynamics have contributed to pandemic phases accompanied by emergent genomic

177 signatures $(1,13)$. Extensive polymorphisms in the spike protein have been documented,

178 including N501Y and E484K mutations that are particularly concerning (14). In this report, we

179 present early genomic analysis of SARS-CoV-2 from an ongoing post-vaccination COVID-19

180 surveillance program among healthcare workers in New Jersey.

181 We detected SARS-CoV-2 in $33(0.15 \%)$ HCPs who were fully vaccinated, none of whom 182 required hospitalization. All symptomatic cases were noted among partially vaccinated HCPs 183 and were self-limiting with only 5 requiring hospitalization. Although our passive surveillance 184 system was intended to capture the HCP vaccinated population who self-reported symptoms or 185 who were exposed to a COVID-19 positive case, and not able to report true prevalence of 186 infections (i.e., mild or asymptomatic infections may be missed), our findings are consistent with 187 emerging reports of incident post-vaccination SARS-CoV-2 infections (15-18). A recent 188 multicenter prospective cohort study in England found vaccine effectiveness upwards of $85 \%$ 189 (19). Our results support high levels of protection afforded by vaccination, particularly among 190 recipients of both doses $(9,15,20-24)$. The majority of cases in our study were among partially 191 vaccinated individuals, emphasizing the importance of personal protective measures, and 192 susceptibility to infection particularly until fully vaccinated $(19,24-27)$.

193 Steep transmission gradients reported locally and regionally have been partly attributed to 194 VOCs, including B.1.1.7 in Europe and U.S., P.1 in Brazil, B.1.351 in South Africa, B.1.617.2 in 195 India and B.1.526 in New York State $(6-8,11,28)$. Although the pathogen characteristics 196 attributable to the spread of these variants at the population-level are difficult to assess, 197 mathematical modeling, genomic and experimental studies have demonstrated increased 198 transmissibility and immune evasion properties, including reduced vaccine-induced antibody 
medRxiv preprint doi: https://doi.org/10.1101/2021.06.30.21259761; this version posted July 5, 2021. The copyright holder for this preprint (which was not certified by peer review) is the author/funder, who has granted medRxiv a license to display the preprint in perpetuity. It is made available under a CC-BY-NC-ND 4.0 International license .

neutralization in vitro $(2,3,6,14)$. Whether the rollout of vaccination would offer selective

200 advantage to VOCs is a critical question to determine.

201 A recent study from Washington State found that all SARS-CoV-2 vaccine breakthroughs

202 were VOCs. Of significance, those VOCs harboring immune evasion properties (B.1.351,

203 B.1.427, B.1.429, and P1) were enriched compared to B.1.1.7 lineages among vaccine

204 breakthrough cases when compared to cases in the general population (29). Other outbreaks

205 have been reported among vaccinated individuals implicating SARS-CoV-2 strains harboring 206 E484K, a noted immune evasion conferring polymorphism (20). A recent study where two VOCs

207 (B.1.351 and B.1.1.7) dominate the viral population, indicate reduced vaccine effectiveness

208 against both variants at specific time windows. Reduced effectiveness against B.1.351 at least 7

209 days after the second BNT162b2 dose, and against B.1.1.7 between 2 weeks after the first dose

210 and 6 days after the second dose were reported (24). However, among fully vaccinated HCPs

211 the VOC proportions between cases and controls were comparable, consistent with our

212 findings. These studies reinforce the need to fully vaccinate to achieve high levels of protection

213 afforded by vaccination (9).

214 In our study, despite an increasing trend in the proportion of N501Y and E484K variants in

215 the overall population (Figure 2), we do not find early evidence of genotypic enrichment of 216 polymorphisms within the NTD or RBD region of the spike protein gene among our fully

217 vaccinated HCPs. Although 44\% of the strains recovered from fully vaccinated HCPs harbored

218 mutations of concern ( $6 \mathrm{~N} 501 \mathrm{Y}$ and $1 \mathrm{E} 484 \mathrm{~K})$, they were similar in proportion to strains

219 circulating in the community during the same time period. Our WGS analysis suggests N501Y

220 harboring strains belong to the B1.1.7 lineage and the E484K mutants to the B.1.526 lineage,

221 both highly prevalent lineages in Northeastern US (12, 30). All N501Y mutants were detected

222 among fully vaccinated HCPs, half of which failed to generate WGS data due to higher Ct

223 values, a likely consequence of vaccination (31). 
medRxiv preprint doi: https://doi.org/10.1101/2021.06.30.21259761; this version posted July 5, 2021. The copyright holder for this preprint (which was not certified by peer review) is the author/funder, who has granted medRxiv a license to display the preprint in perpetuity. It is made available under a CC-BY-NC-ND 4.0 International license .

A recent report showed that B.1.1.7 upregulates key innate immune antagonists likely 225 increasing the transmission potential of this VOC (32). Interestingly, mRNA vaccines have 226 shown high levels of efficacy against B.1.1.7 infections (22). Overall, the genomic diversity of 227 SARS-CoV-2 recovered post-vaccination appears to proportionally represent the observed viral 228 diversity within the community. We acknowledge that our estimates may be skewed by under229 sampling of asymptomatic infections among fully vaccinated individuals (33), and likely affected 230 by test seeking behavioral bias (24). However, our results are consistent with those from a large 231 nationwide surveillance program of COVID-19 vaccine breakthrough infections that found the 232 proportion of reported vaccine breakthrough infections attributed to VOCs to be similar to the 233 proportion of these variants circulating throughout the United States (27).

234 There is mounting evidence that currently available vaccines, including those used in our 235 population, are highly effective against VOCs. The reports of VOC enrichment among post236 vaccinated individuals, despite small sample sizes, warrant surveillance. Our study findings are 237 preliminary yet highlights the importance of full vaccination against circulating variants, including 238 VOCs, and the need to continue SARS-CoV-2 genomic surveillance as vaccination coverage 239 expands, pathogen evolves and immunity wanes.

\section{METHODS}

242 Post-vaccination COVID-19 surveillance program.

243 Since the first mRNA vaccines were administered in December 2020 among the 37,500 $\mathrm{HMH}$ 244 employees, we initiated a symptoms-based surveillance program to identify and report the 245 status of each vaccinated person in the Electronic Medical Record (EMR). This regularly 246 updated list was cross-referenced daily against the results of all SARS-Cov-2 nucleic acid 247 amplification tests (NAAT) in the $\mathrm{HMH}$ network. As a result, we were able to identify all 248 vaccinated employees who tested positive for COVID-19 by NAAT after routine screening or 
medRxiv preprint doi: https://doi.org/10.1101/2021.06.30.21259761; this version posted July 5, 2021. The copyright holder for this preprint (which was not certified by peer review) is the author/funder, who has granted medRxiv a license to display the preprint in perpetuity. It is made available under a CC-BY-NC-ND 4.0 International license .

249 after reporting out sick. Non-team members who were vaccinated at our mass-vaccination site

250 or by physician report (and were thus in the HMH EMR) and subsequently tested positive for

251 COVID-19 by NAAT were also similarly identified. The study was approved by Hackensack

252 Meridian Health Institutional Review Board (IRB).

254 Whole genome sequencing and phylogenetic analysis

255 SARS-CoV-2 targeted assay libraries were prepared using the Molecular Loop Viral RNA Target

256 Capture Kit (Molecular Loop) or QIAseq FX DNA Library UDI Kit (QIAGEN), in accordance with

257 manufacturer's recommendations. Final libraries were quantified using fluorescent-based

258 assays including PicoGreen (Life Technologies), Qubit Fluorometer (Invitrogen), and Fragment

259 Analyzer (Advanced Analytics). Final libraries were sequenced on a NovaSeq 6000 sequencer

260 (v1 chemistry) with 2x150bp.

261

262 For QIAseq libraries, read pairs that did not contain a single 19bp seed k-mer in common with

263 the SARS-CoV-2 genome reference (NC_045512.2) were discarded. Adapter sequences and

264 low-quality bases $(Q<20)$ were trimmed from the 3' end of the remaining reads, using Cutadapt

265 v2.10 (34). Sequences corresponding to the amplicon primers were also clipped from the 5' end

266 of reads. Processed read pairs were then aligned to the SARS-CoV-2 reference genome, using

267 BWA-MEM v0.7.17 (35) and only read pairs with at least one alignment spanning a minimum of

$26850 \mathrm{bp}$ in the reference were kept.

270 For Molecular Loop libraries, the two 5bp UMls located at the 5' end of each mate were first

271 clipped and combined into a single UMI tag. Additional $25 \mathrm{bp}$, corresponding to the molecular

272 inversion probes, were also clipped from the 5' end of each read. Next, read pairs that did not

273 contain a single 19bp seed k-mer in common with the SARS-CoV-2 genome reference

274 (NC_045512.2) were discarded and adapter sequences and low-quality bases $(\mathrm{Q}<20)$ were 
medRxiv preprint doi: https://doi.org/10.1101/2021.06.30.21259761; this version posted July 5, 2021. The copyright holder for this preprint (which was not certified by peer review) is the author/funder, who has granted medRxiv a license to display the preprint in perpetuity.

It is made available under a CC-BY-NC-ND 4.0 International license .

275 trimmed from the 3' end of the remaining reads, using Cutadapt v2.10 (34). Processed reads

276 pairs were then merged using NGmerge v0.2 (36) , allowing for dovetailed alignments. The

277 resulting single end reads were mapped against the SARS-CoV-2 genome reference using

278 BWA-MEM v0.7.17 (35) and the resulting alignments filtered using the following criteria: 1)

279 reference span $\geq 50 \mathrm{bp}, 2)$ quality $\geq 60$, and 3) maximum soft-clip length on either end $\leq 30 \mathrm{bp}$.

280 Next, reads representing the same original molecule were identified based on their shared UMI

281 and alignment position and used to draw the molecule consensus sequence, taking into account

282 base quality scores. Molecule sequences were then realigned to the SARS-CoV-2 genome

283 reference using BWA-MEM v0.7.17 (35). Finally, genome sequences were determined either

284 by read (QIAseq) or molecule (Molecular Loop) alignment pileup consensus calling with a

285 minimum support of 5 reads/molecules.

287 The resulting SARS-CoV-2 viral genome sequences were characterized by Nextclade CLI (v1)

288 (https://clades.nextstrain.org/) to assign Nextstrain clades (37). SARS-CoV-2 lineages were

289 determined using Pangolin v3.1.3 (https://github.com/cov-lineages/pangolin) and GISAID clades

290 were determined based upon the clade-specific marker variants from https://www.gisaid.org

291 (38). The genomes were aligned using nextalign v1.0.0 (https://github.com/neherlab/nextalign),

292 using default setting. A maximum likelihood phylogenetic tree was constructed using IQ-TREE

293 v2.1.2 (39) with automatic model selection and 1000-bootstrap replicates. The resulting tree

294 was annotated using ITOL v6 (40).

\section{Population sampling and screening of SARS-CoV-2}

297 SARS-CoV-2 positive swabs collected from seven HMH network hospitals were shipped to CDI

298 on a weekly basis and stored at $-80^{\circ} \mathrm{C}$. 1,404 swabs collected during the same time frame as

299 the vaccinated samples were randomly selected and subjected to a molecular beacon-based

300 real-time asymmetric PCR and melting curve analysis to identify the SARS-CoV-2 E484K/Q and 
medRxiv preprint doi: https://doi.org/10.1101/2021.06.30.21259761; this version posted July 5, 2021. The copyright holder for this preprint (which was not certified by peer review) is the author/funder, who has granted medRxiv a license to display the preprint in perpetuity. It is made available under a CC-BY-NC-ND 4.0 International license.

301 N501Y mutations, as previously described (10). In brief, $50 \mu$ l aliquots of SARS-CoV-2 swab

302 specimens were treated by proteinase $\mathrm{K}$ and heated at $95^{\circ} \mathrm{C}$ for $5 \mathrm{~min} .5 \mathrm{ul}$ of heat inactivated

303 sample was used as template for the asymmetric RT-PCR testing on a Mic Real Time PCR

304 Cycler (Bio Molecular Systems, software micPCRv2.8.13). Based on the different melting

305 profiles (Tm) of E484 and N501 molecular beacons in each sample, the E484K and N501Y

306 mutations were determined.

307

308 Statistical analysis

309 Fisher's exact or chi-square tests, as appropriate, were used to examine whether the spike

310 protein NTD/RBD mutations were enriched in the vaccinated HCPs $(n=68)$ in comparison with

311 the non-vaccinated patients ( $n=281$ ). SPSS, version 17.0 (IBM Corp., Armonk, NY) was used

312 for statistical analyses and two-tailed $P$ values $\leq 0.05$ were considered statistically significant.

\section{Data availability}

315 The SARS-CoV-2 genomes sequenced in this study were deposited in GISAID

316 (www.gisaid.org). Sequences can be accessed by searching records from both the originating

317 lab at Hackensack Medical Center and the submitting lab at the New York Genome Center. 
medRxiv preprint doi: https://doi.org/10.1101/2021.06.30.21259761; this version posted July 5, 2021. The copyright holder for this preprint (which was not certified by peer review) is the author/funder, who has granted medRxiv a license to display the preprint in perpetuity. It is made available under a CC-BY-NC-ND 4.0 International license.

319 FIGURE 1. Clinical characteristics of 83 COVID-19 vaccinated HCPs and their SARS-CoV-2 S

320 protein E484 and N501 genotypes. The samples were ordered by the time of diagnosis, with the

321 the first case detection week denoted as "0".

327 FIGURE 2. Prevalence of E484K/Q and N501Y mutants among SARS-Cov-2 samples from 328 non-vaccinated individuals from January to April 2021.

333 FIGURE 3. Maximum Likelihood Phylogenetic tree of 349 SARS-CoV-2 genomes isolated from

334 vaccinated and non-vaccinated populations. The tree is rooted to the SARS-CoV-2 Wuhan-Hu-1

335 reference genome (NC_045512.2). The scale represents 0.0001 nucleotide substitutions per

336 site. The vaccination conditions are color coded at the tree tips: purple, black and white tips

337 denote single-dose, double-dose vaccine and non-vaccination, respectively. The SARS-CoV-2

338 Pangolin lineage is illustrated as a color bar and the S protein NTD/RBD mutations are shown

339 as a heatmap on the right panel. 
medRxiv preprint doi: https://doi.org/10.1101/2021.06.30.21259761; this version posted July 5, 2021. The copyright holder for this preprint (which was not certified by peer review) is the author/funder, who has granted medRxiv a license to display the preprint in perpetuity.

\section{References:}

343 1. Kissler SM, Tedijanto C, Goldstein E, Grad YH, Lipsitch M. 2020. Projecting the 344 transmission dynamics of SARS-CoV-2 through the postpandemic period. Science $345 \quad 368: 860-868$.

2. Hodcroft EB, Zuber M, Nadeau S, Vaughan TG, Crawford KHD, Althaus CL, Reichmuth

3. Starr TN, Greaney AJ, Addetia A, Hannon WW, Choudhary MC, Dingens AS, Li JZ, treat COVID-19. Science 371:850-854.

4. Greaney AJ, Loes AN, Crawford KHD, Starr TN, Malone KD, Chu HY, Bloom JD. domain that affect recognition by polyclonal human plasma antibodies. Cell Host

357 5. Boehm E, Kronig I, Neher RA, Eckerle I, Vetter P, Kaiser L, Geneva Centre for Emerging Viral D. 2021. Novel SARS-CoV-2 variants: the pandemics within the pandemic. Clin Microbiol Infect doi:10.1016/j.cmi.2021.05.022.

360 6. Volz E, Mishra S, Chand M, Barrett JC, Johnson R, Geidelberg L, Hinsley WR, Laydon 361 DJ, Dabrera G, O'Toole A, Amato R, Ragonnet-Cronin M, Harrison I, Jackson B, Ariani CV, Boyd O, Loman NJ, McCrone JT, Goncalves S, Jorgensen D, Myers R, Hill V, 363 Jackson DK, Gaythorpe K, Groves N, Sillitoe J, Kwiatkowski DP, consortium C-GU, 
medRxiv preprint doi: https://doi.org/10.1101/2021.06.30.21259761; this version posted July 5, 2021. The copyright holder for this preprint (which was not certified by peer review) is the author/funder, who has granted medRxiv a license to display the preprint in perpetuity. It is made available under a CC-BY-NC-ND 4.0 International license .

Flaxman S, Ratmann O, Bhatt S, Hopkins S, Gandy A, Rambaut A, Ferguson NM. 2021. Assessing transmissibility of SARS-CoV-2 lineage B.1.1.7 in England. Nature 593:266269.

367 7. Tegally H, Wilkinson E, Giovanetti M, Iranzadeh A, Fonseca V, Giandhari J, Doolabh D, Hardie D, Marais G, Hsiao NY, Korsman S, Davies MA, Tyers L, Mudau I, York D, Maslo C, Goedhals D, Abrahams S, Laguda-Akingba O, Alisoltani-Dehkordi A, Godzik Rocha EC, de Souza LM, de Pinho MC, Araujo LJT, Malta FSV, de Lima AB, Silva 372:815-821.

A, Jansen KU, Sahin U, Xie X, Dormitzer PR, Shi PY. 2021. BNT162b2-elicited 
neutralization of B.1.617 and other SARS-CoV-2 variants. Nature doi:10.1038/s41586-

10. Zhao Y, Lee A, Composto K, Cunningham MH, Mediavilla JR, Fennessey S, Corvelo A, Chow KF, Zody M, Chen L, Kreiswirth BN, Perlin DS. 2021. A novel diagnostic test to screen SARS-CoV-2 variants containing E484K and N501Y mutations. Emerg Microbes Infect 10:994-997.

11. Annavajhala MK, Mohri H, Zucker JE, Sheng Z, Wang P, Gomez-Simmonds A, Ho DD, Uhlemann AC. 2021. A Novel SARS-CoV-2 Variant of Concern, B.1.526, Identified in New York. medRxiv doi:10.1101/2021.02.23.21252259.

12. Thompson CN, Hughes S, Ngai S, Baumgartner J, Wang JC, McGibbon E, Devinney K, AK, Rakeman JL, PhD, Fine AD. 2021. Rapid Emergence and Epidemiologic Characteristics of the SARS-CoV-2 B.1.526 Variant - New York City, New York, January 1-April 5, 2021. MMWR Morb Mortal Wkly Rep 70:712-716.

13. Cobey S, Larremore DB, Grad YH, Lipsitch M. 2021. Concerns about SARS-CoV-2 evolution should not hold back efforts to expand vaccination. Nat Rev Immunol 21:330-

404 14. Wang P, Nair MS, Liu L, Iketani S, Luo Y, Guo Y, Wang M, Yu J, Zhang B, Kwong PD, Graham BS, Mascola JR, Chang JY, Yin MT, Sobieszczyk M, Kyratsous CA, Shapiro L, Sheng Z, Huang Y, Ho DD. 2021. Antibody resistance of SARS-CoV-2 variants B.1.351 and B.1.1.7. Nature 593:130-135. 
medRxiv preprint doi: https://doi.org/10.1101/2021.06.30.21259761; this version posted July 5, 2021. The copyright holder for this preprint (which was not certified by peer review) is the author/funder, who has granted medRxiv a license to display the preprint in perpetuity. It is made available under a CC-BY-NC-ND 4.0 International license .

WP, Connor J, Pierre C, Jacobson KR. 2021. COVID-19 vaccine impact on rates of SARS-CoV-2 cases and post vaccination strain sequences among healthcare workers at an urban academic medical center: a prospective cohort study. medRxiv doi:10.1101/2021.03.30.21254655.

16. Daniel W, Nivet M, Warner J, Podolsky DK. 2021. Early Evidence of the Effect of SARS-CoV-2 Vaccine at One Medical Center. N Engl J Med 384:1962-1963.

17. Keehner J, Horton LE, Pfeffer MA, Longhurst CA, Schooley RT, Currier JS, Abeles SR, Torriani FJ. 2021. SARS-CoV-2 Infection after Vaccination in Health Care Workers in California. N Engl J Med 384:1774-1775.

18. Teran RA, Walblay KA, Shane EL, Xydis S, Gretsch S, Gagner A, Samala U, Choi H, Zelinski C, Black SR. 2021. Postvaccination SARS-CoV-2 Infections Among Skilled Nursing Facility Residents and Staff Members - Chicago, Illinois, December 2020-March 2021. MMWR Morb Mortal Wkly Rep 70:632-638.

19. Hall VJ, Foulkes S, Saei A, Andrews N, Oguti B, Charlett A, Wellington E, Stowe J, Gillson N, Atti A, Islam J, Karagiannis I, Munro K, Khawam J, Chand MA, Brown CS, Ramsay M, Lopez-Bernal J, Hopkins S, Group SS. 2021. COVID-19 vaccine coverage in health-care workers in England and effectiveness of BNT162b2 mRNA vaccine against infection (SIREN): a prospective, multicentre, cohort study. Lancet 397:1725-1735.

20. Cavanaugh AM, Fortier S, Lewis P, Arora V, Johnson M, George K, Tobias J, Lunn S, Miller T, Thoroughman D, Spicer KB. 2021. COVID-19 Outbreak Associated with a SARS-CoV-2 R.1 Lineage Variant in a Skilled Nursing Facility After Vaccination Program - Kentucky, March 2021. MMWR Morb Mortal Wkly Rep 70:639-643. 
medRxiv preprint doi: https://doi.org/10.1101/2021.06.30.21259761; this version posted July 5, 2021. The copyright holder for this preprint (which was not certified by peer review) is the author/funder, who has granted medRxiv a license to display the preprint in perpetuity. It is made available under a CC-BY-NC-ND 4.0 International license .

432 21. Dagan N, Barda N, Kepten E, Miron O, Perchik S, Katz MA, Hernan MA, Lipsitch M,

433 Reis B, Balicer RD. 2021. BNT162b2 mRNA Covid-19 Vaccine in a Nationwide Mass

$434 \quad$ Vaccination Setting. N Engl J Med 384:1412-1423.

435 22. Haas EJ, Angulo FJ, McLaughlin JM, Anis E, Singer SR, Khan F, Brooks N, Smaja M, 436 Mircus G, Pan K, Southern J, Swerdlow DL, Jodar L, Levy Y, Alroy-Preis S. 2021.

437 Impact and effectiveness of mRNA BNT162b2 vaccine against SARS-CoV-2 infections

438 and COVID-19 cases, hospitalisations, and deaths following a nationwide vaccination

439 campaign in Israel: an observational study using national surveillance data. Lancet

$440 \quad 397: 1819-1829$.

441 23. Angel Y, Spitzer A, Henig O, Saiag E, Sprecher E, Padova H, Ben-Ami R. 2021.

$442 \quad$ Association Between Vaccination With BNT162b2 and Incidence of Symptomatic and 443 Asymptomatic SARS-CoV-2 Infections Among Health Care Workers. JAMA 444 doi:10.1001/jama.2021.7152.

445 24. Kustin T, Harel N, Finkel U, Perchik S, Harari S, Tahor M, Caspi I, Levy R, Leshchinsky 446 M, Ken Dror S, Bergerzon G, Gadban H, Gadban F, Eliassian E, Shimron O, Saleh L, 447 Ben-Zvi H, Keren Taraday E, Amichay D, Ben-Dor A, Sagas D, Strauss M, Shemer Avni 448 Y, Huppert A, Kepten E, Balicer RD, Netzer D, Ben-Shachar S, Stern A. 2021. Evidence 449 for increased breakthrough rates of SARS-CoV-2 variants of concern in BNT162b2450 mRNA-vaccinated individuals. Nat Med doi:10.1038/s41591-021-01413-7.

451 25. Abu-Raddad LJ, Chemaitelly H, Butt AA, National Study Group for C-V. 2021.

452 Effectiveness of the BNT162b2 Covid-19 Vaccine against the B.1.1.7 and B.1.351

453 Variants. N Engl J Med doi:10.1056/NEJMc2104974. 
medRxiv preprint doi: https://doi.org/10.1101/2021.06.30.21259761; this version posted July 5, 2021. The copyright holder for this preprint (which was not certified by peer review) is the author/funder, who has granted medRxiv a license to display the preprint in perpetuity. It is made available under a CC-BY-NC-ND 4.0 International license .

454 26. Chodick G, Tene L, Rotem RS, Patalon T, Gazit S, Ben-Tov A, Weil C, Goldshtein I,

455 Twig G, Cohen D, Muhsen K. 2021. The effectiveness of the TWO-DOSE BNT162b2 vaccine: analysis of real-world data. Clin Infect Dis doi:10.1093/cid/ciab438.

457 27. Team CC-VBCI. 2021. COVID-19 Vaccine Breakthrough Infections Reported to CDC United States, January 1-April 30, 2021. MMWR Morb Mortal Wkly Rep 70:792-793.

459 28. Candido DS, Claro IM, de Jesus JG, Souza WM, Moreira FRR, Dellicour S, Mellan TA, du Plessis L, Pereira RHM, Sales FCS, Manuli ER, Theze J, Almeida L, Menezes MT, Voloch CM, Fumagalli MJ, Coletti TM, da Silva CAM, Ramundo MS, Amorim MR, Hoeltgebaum HH, Mishra S, Gill MS, Carvalho LM, Buss LF, Prete CA, Jr., Ashworth J, Nakaya HI, Peixoto PS, Brady OJ, Nicholls SM, Tanuri A, Rossi AD, Braga CKV,

29. McEwen AE, Cohen S, Bryson-Cahn C, Liu C, Pergam SA, Lynch J, Schippers A, Strand MW, Jr., Castineiras T, Lazari CS, et al. 2020. Evolution and epidemic spread of SARSCoV-2 in Brazil. Science doi:10.1126/science.abd2161. breakthrough infections of SARS-CoV-2 in Washington State. medRxiv doi:10.1101/2021.05.23.21257679:2021.05.23.21257679.

30. West AP, Wertheim JO, Wang JC, Vasylyeva TI, Havens JL, Chowdhury MA, Gonzalez E, Fang CE, Di Lonardo SS, Hughes S, Rakeman JL, Lee HH, Barnes CO, Gnanapragasam PNP, Yang Z, Gaebler C, Caskey M, Nussenzweig MC, Keeffe JR, 
medRxiv preprint doi: https://doi.org/10.1101/2021.06.30.21259761; this version posted July 5, 2021. The copyright holder for this preprint (which was not certified by peer review) is the author/funder, who has granted medRxiv a license to display the preprint in perpetuity.

It is made available under a CC-BY-NC-ND 4.0 International license .

Bjorkman PJ. 2021. Detection and characterization of the SARS-CoV-2 lineage B.1.526 in New York. bioRxiv doi:10.1101/2021.02.14.431043.

479 31. Levine-Tiefenbrun M, Yelin I, Katz R, Herzel E, Golan Z, Schreiber L, Wolf T, Nadler

32. Thorne LG, Bouhaddou M, Reuschl AK, Zuliani-Alvarez L, Polacco B, Pelin A, Batra J,

490 33. Hay JA, Kennedy-Shaffer L, Kanjilal S, Lennon NJ, Gabriel SB, Lipsitch M, Mina MJ. 2021. Estimating epidemiologic dynamics from cross-sectional viral load distributions.

493 34. Kechin A, Boyarskikh U, Kel A, Filipenko M. 2017. cutPrimers: A New Tool for 494 Accurate Cutting of Primers from Reads of Targeted Next Generation Sequencing. J Comput Biol 24:1138-1143.

496 35. Li H, Durbin R. 2009. Fast and accurate short read alignment with Burrows-Wheeler 497 transform. Bioinformatics 25:1754-60.

498 36. Gaspar JM. 2018. NGmerge: merging paired-end reads via novel empirically-derived models of sequencing errors. BMC Bioinformatics 19:536. 
500 37. Hadfield J, Megill C, Bell SM, Huddleston J, Potter B, Callender C, Sagulenko P,

$501 \quad$ Bedford T, Neher RA. 2018. Nextstrain: real-time tracking of pathogen evolution.

$502 \quad$ Bioinformatics 34:4121-4123.

503 38. Elbe S, Buckland-Merrett G. 2017. Data, disease and diplomacy: GISAID's innovative $504 \quad$ contribution to global health. Glob Chall 1:33-46.

505 39. Nguyen LT, Schmidt HA, von Haeseler A, Minh BQ. 2015. IQ-TREE: a fast and 506 effective stochastic algorithm for estimating maximum-likelihood phylogenies. Mol Biol $507 \quad$ Evol 32:268-74.

508 40. Letunic I, Bork P. 2019. Interactive Tree Of Life (iTOL) v4: recent updates and new 509 developments. Nucleic Acids Res 47:W256-W259. 


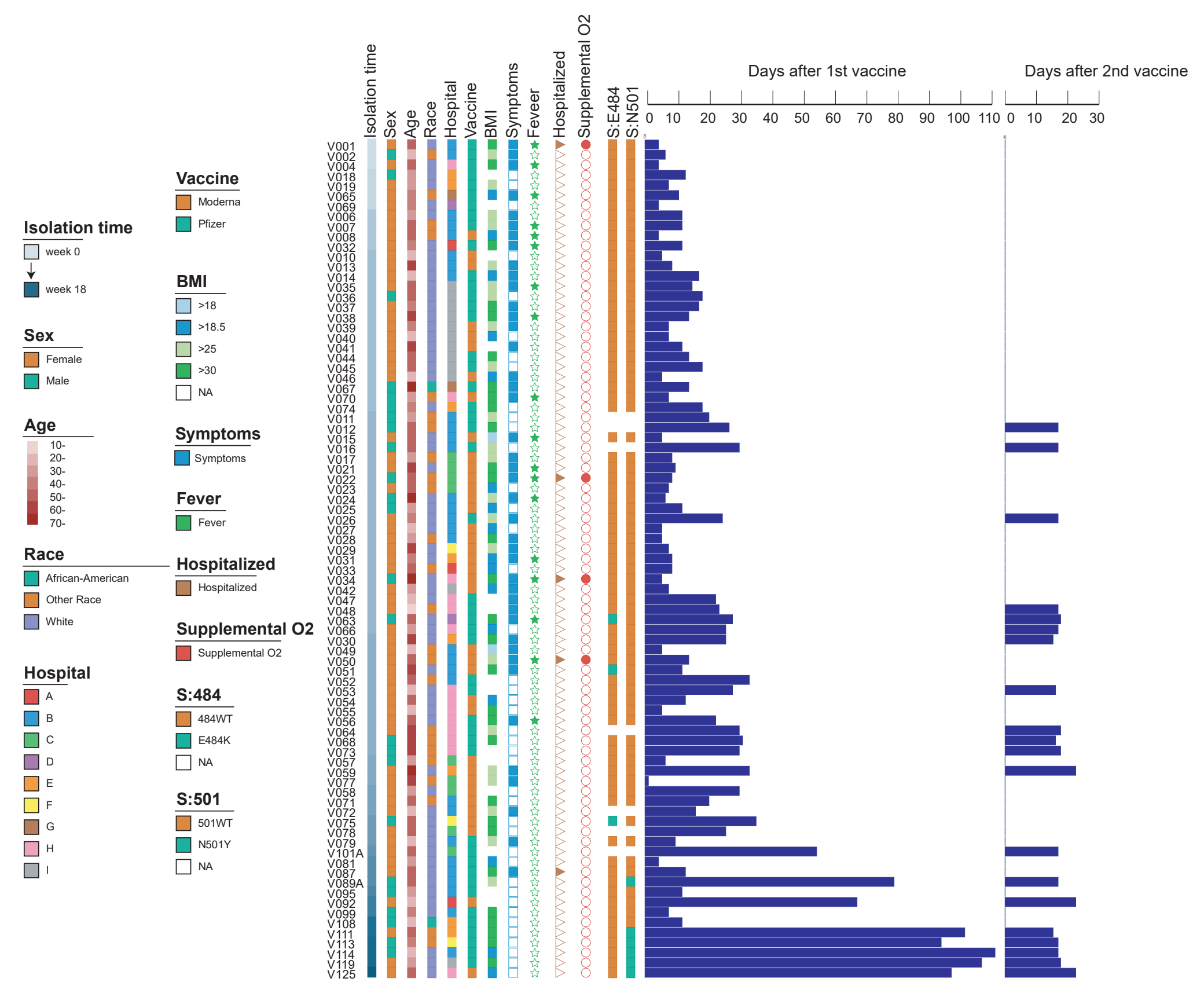


medRxiv preprint doi: https://doi.org/10.1101/2021.06.30.21259761; this version posted July 5, 2021. The copyright holder for this preprint (which was not certified by peer review) is the author/funder, who has granted medRxiv a license to display the preprint in perpetuity.

It is made available under a CC-BY-NC-ND 4.0 International license .

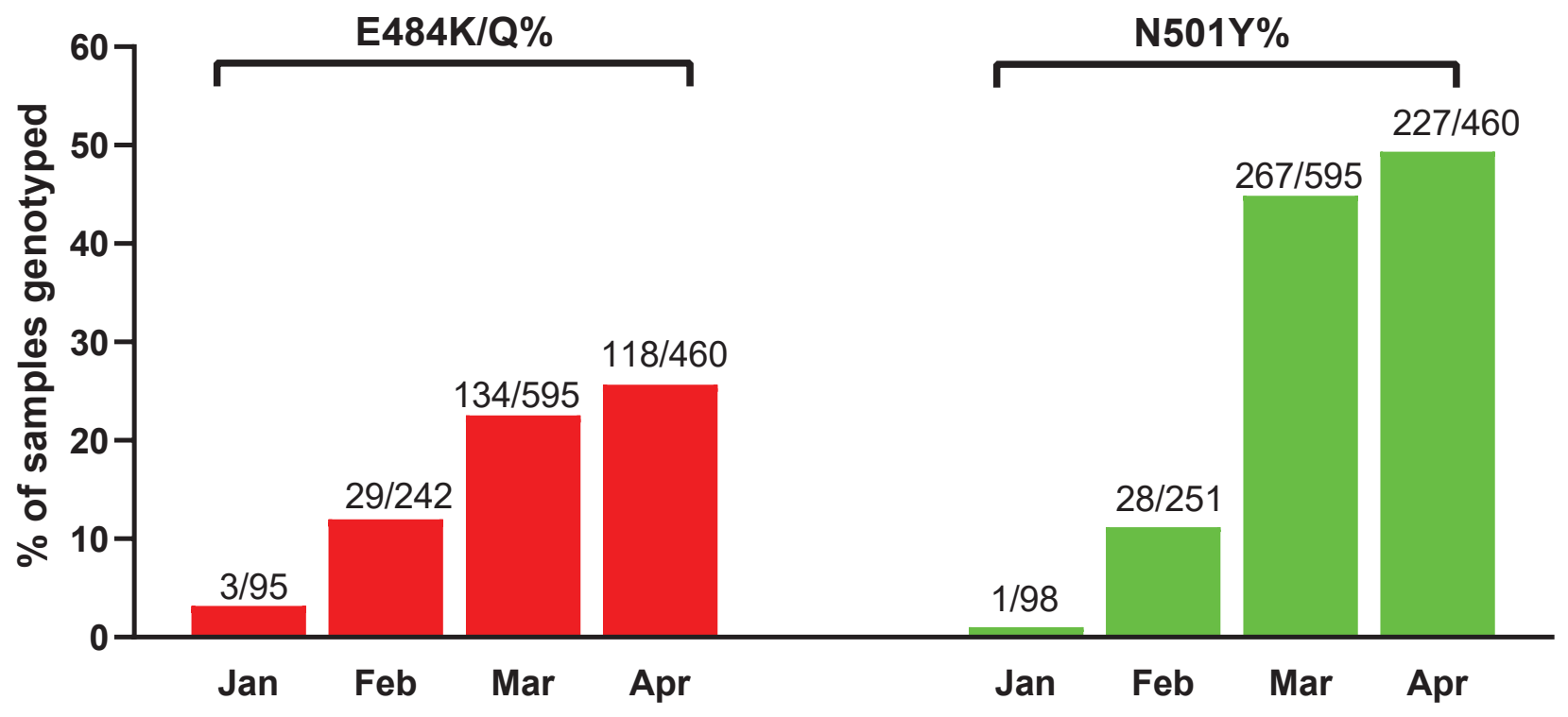




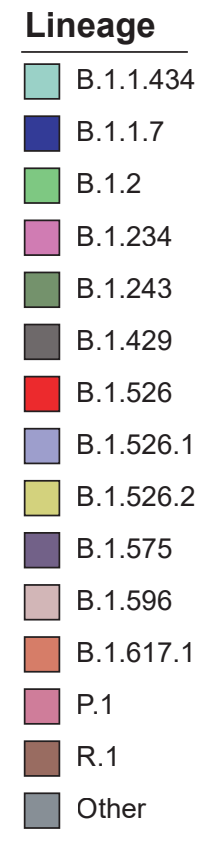

\section{NTD/RBD mutation}

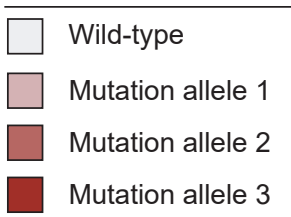
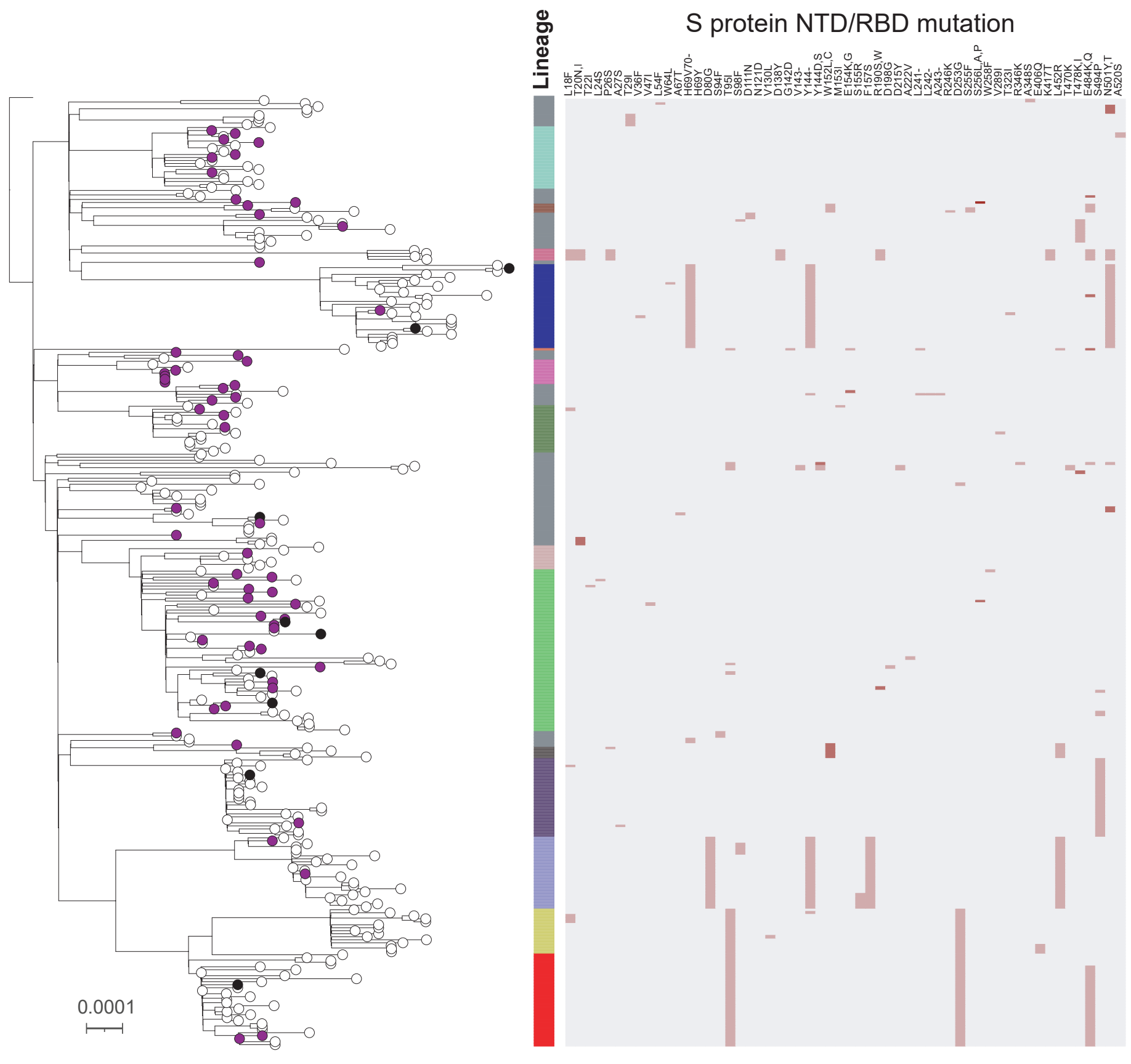